\title{
The impact of erlotinib use in non-small-cell lung cancer patients treated in a private reference general hospital and in a private cancer clinic from 2005 to 2011
}

\author{
O impacto do uso do erlotinibe em pacientes portadores de neoplasia de pulmão \\ de não pequenas células tratados em um hospital geral de referência e \\ clínica particular de oncologia no período de 2005 a 2011
} Cinthia Leite Frizzera Borges Bognar ${ }^{1}$, Sergio Daniel Simon ${ }^{1,2}$, Rene Claudio Gansl $1^{1,2}$, Roberto Abramoff Ref, $^{1,2}$,
Marcelo Aisen ${ }^{1}$, Gilberto de Lima Lopes Junior ${ }^{1}$, Oren Smaletz ${ }^{2}$, Stela Verzinhasse Peres ${ }^{3}$, Jacques Tabacof ${ }^{1,2}$

\begin{abstract}
Objective: To report the demographic data and clinical outcomes of non-small-cell lung cancer patients exposed to erlotinib in any line of treatment. Methods: This was a retrospective cohort study of nonsmall-cell lung cancer patients from a reference general hospital and a private oncology clinic, who received erlotinib from 2005 to 2011. Statistical analysis was performed and we evaluated demographic data and response to treatment, by correlating the results of this first cohort published in Brazil with results of current literature. Results: A total of 44 patients were included; $65.9 \%$ were diagnosed with adenocarcinoma, and $63.6 \%$ had metastatic disease. The mean age was 63.3 years. The median follow-up was 47.9 months. Epidermal growth factor receptor mutation screening was performed in $22.7 \%$ of patients $(n=10)$, with mutation present in $30 \%$ of patients. The median overall survival was 46.3 months, and there was a higher probability of survival at 60 months for females compared to males $(29.4 \%$ versus $15.8 \% ; p=0.042$ ). The other variables did not present significant statistical difference. Conclusion: We collected the largest cohort of patients with non-small-cell lung cancer who have used erlotinib in Brazil to date, and demonstrated that outcomes of patients treated at our clinic during the study period were consistent with the results of current literature in similar patients.
\end{abstract}

Keywords: Carcinoma, non-small cell lung; Genes, erbB-1; Receptor, epidermal growth factor; Protein kinase inhibitors; Antineoplastic agents

\section{RESUMO}

Objetivo: Relatar as características demográficas e a evolução de pacientes com neoplasia de pulmão de não pequenas células que receberam erlotinibe em qualquer linha de tratamento. Métodos: Coletamos retrospectivamente dados de pacientes portadores de neoplasia de pulmão de não pequenas células que receberam erlotinibe em qualquer linha de tratamento em um hospital geral de referência e em uma clínica particular de oncologia em São Paulo, no período de 2005 a 2011. Foi realizada a análise estatística e foram avaliados aspectos demográficos e resposta ao tratamento estabelecido, correlacionando os resultados dessa primeira coorte publicada no Brasil com resultados da literatura vigente. Resultados: Foram avaliados 44 pacientes, dos quais $65,9 \%$ eram portadores de adenocarcinoma e $63,6 \%$ tinham doença metastática. A média de idade foi de 63,3 anos. 0 seguimento mediano foi de 47,9 meses. A pesquisa de mutação do receptor do fator de crescimento epidérmico foi realizada em $22,7 \%$ dos pacientes $(n=10)$, resultando positiva em $30 \%$ dos avaliados. A sobrevida global mediana foi de 46,3 meses, e observou-se uma probabilidade maior de sobrevida em 60 meses para o grupo feminino, quando comparado ao grupo masculino $(29,4 \%$ versus $15,8 \% ; p=0,042)$. As demais variáveis não apresentaram diferença estatística significativa. Conclusão: Coletamos a maior sequência de pacientes com neoplasia de pulmão de não pequenas células que fizeram uso de erlotinibe no Brasil até a data vigente e demonstramos que a evolução dos pacientes tratados no período avaliado teve resultados concordantes com os da literatura vigente em pacientes semelhantes.

\footnotetext{
'Centro Paulista de Oncologia, São Paulo, SP, Brazil.

${ }^{2}$ Hospital Israelita Albert Einstein, São Paulo, SP, Brazil.

${ }^{3}$ Universidade de São Paulo, SP, Brazil.

Corresponding author: Jacques Tabacof - Avenida Brigadeiro Faria Lima, 4,300 - Vila Olímpia - Zip code: 04538-132 - São Paulo, SP, Brazil - Phone: (55 11) 3067-5400 - E-mail: jataba@uol.com.br Received on: Feb 2, 2015 - Accepted on: Apr 23, 2015
}

Conflict of interest: none.

DOI: 10.1590/S1679-45082015A03326 
Descritores: Carcinoma pulmonar de células não pequenas; Genes erbB-1; Receptor do fator de crescimento epidérmico; Inibidores de proteínas quinases; Antineoplásicos

\section{INTRODUCTION}

Lung cancer is the primary cause of death by cancer in men and women worldwide. ${ }^{(1)}$ In Brazil, it is estimated that approximately 16,400 new cases of lung cancer in men were found in 2014. In 2011, the gross mortality rate by lung cancer in the country was 14.54 per 100 thousand men. ${ }^{(2)}$ Non-small-cell lung cancer (NSCLC) accounts to $80 \%$ of lung neoplasms, and the World Health Organization classification divides it according to histology. The main types are adenocarcinoma, squamous cell carcinoma, large-cell carcinoma. ${ }^{(3)}$

The standard treatment for advanced NSCLC (clinical stage IIIb or higher) is based on chemotherapy with platinum (combinations of two drugs), or targetdrugs, depending on the presence or not of mutations present in the neoplastic cell. ${ }^{(4-6)}$

The epidermal growth factor receptor (EGFR) has tyrosine kinase action and regulates apoptosis, angiogenesis and cellular adhesion. Superexpression or aberrant expression of the EGFR (HER1) can be found in some cases of NSCLC, most commonly in nonsmoking patients with adenocarcinoma. ${ }^{(7-9)}$

Erlotinib is a selective of EGFR tyrosine kinase inhibitor. It reduces autophosphorylation of EGFR in intact tumor cells and the proliferation of the EGFRdependent cell, blocking the start of the cellular cycle in the G1 phase. It was approved by the Food and Drug Administration for treatment of locally advanced or metastatic NSCLC in 2004. Monotherapy with this drug proves to be effective and more active for patients with NSCLC and mutated EGFR. ${ }^{(10-12)}$

The use of erlotinib has been shown to be effective in the treatment of NSCLC with mutated EGFR, thus rousing great interest in factors for a better response and better survival. Various factors have been studied related to the greater or lesser efficacy of the medication. The presence of mutations such as EGFR and the Kirsten rat sarcoma viral oncogene, known as KRAS, as well as the skin rash when initiating the medication in patients with non-mutated EGFR, demographic factors such as Asian race, presence or absence of smoking are considered independent factors for response to erlotinib. ${ }^{(13-15)}$

Patients with EGFR-activating mutations, such as L858R in exon 21 and deletions in exon 19, show improvement in symptoms and a higher response rate with the use of erlotinib. Investigation of the EGFR mutation is essential for the decision to initiate use of erlotinib, and its absence is justified only by the impossibility of performing it, such as, for example, due to scarcity of material. This mutation was found with greater frequency in non-smoking patients with the adenocarcinoma histological subtype, which, presented with greater sensitivity to gefitinib and erlotinib in one study. $.5,7,8,10,15,16)$

The skin rash also showed a direct relation with response to medication, increasing the objective response and affording greater survival in patients without the EGFR mutation, but not in patients with mutations. Elderly patients also benefited from the use of erlotinib, but at the cost of greater toxicity, even though it is tolerable in most cases..$^{(13,17-21)}$

The subgroup of patients that potentially have greatest benefit from the medication includes those with greatest prevalence of EGFR mutations: Asian patients, of the female gender, with adenocarcinoma subtype, and non-smokers. ${ }^{(7-10,13,22-24)}$

The KRAS gene mutation showed an inverse relation with the response to erlotinib, as well as with the non-coexistence with the EGFR mutation. Treatment with erlotinib in patients with mutated KRAS resulted in worse survival in comparison with the control group, suggesting a possible reduction of responsiveness to erlotinib in the presence of the said mutation. (8,10,19) $^{2}$

\section{OBJECTIVE}

To analyze and describe a series of patients with nonsmall cell lung cancer treated with erlotinib during a period prior to the mandatory investigation of the epidermal growth factor receptor mutation before use of this medication, including retrospective data of overall survival since the diagnosis of metastasis, and histological characteristics and demographic characteristics of the group.

\section{METHODS}

We retrospectively collected data from patients with NSCLC who had received erlotinib in any line of treatment in a private reference general hospital and in a private oncology clinic in São Paulo, during the period of 2005 to 2011.

The sample comprised 44 patients. This was a retrospective cohort study, with median follow-up of 47.9 months. 
Patients were selected according to the following inclusion criteria: patients with histologically confirmed NSCLC treated in a private reference general hospital and in a private oncology clinic in São Paulo during the period from January 1st, 2005, to December 31st, 2011; 18 years of age or more; use of erlotinib for at least one day; receive erlotinib in any line of treatment.

EGFR mutation investigation was not a criterion for the use of erlotinib, since at the time of the study, this mutation was not mandatory for the use of the medication. The research was conducted in accordance with the personal evaluation of each patient's treating physician.

Exclusion criteria included: patients less than 18 years of age; patients with other active neoplasms, except non-melanoma skin cancer; patient whose physician responsible for the medical record did not work at the organizations, or had not authorized review of the record.

The criterion for disease progression, stable disease, or complete or partial response was based on the personal evaluation of the attending physician of each patient.

\section{Statistical analysis}

Statistical analysis of the sample was done by means of absolute and relative frequencies, measures of central tendency (mean and median), and dispersion (standard deviation, minimum, and maximum).

For analysis of overall survival in 60 months, KaplanMeier test was used, and the comparison between curves was made by the log-rank test. Overall survival was calculated between the date of diagnosis of metastases until the last status (alive or dead).

For statistical analyses, the Statistical Package for Social Sciences, version 17 for Windows was used.

A descriptive level of $5 \%(\mathrm{p} \leq 0.050)$ was adopted for statistical significance.

\section{RESULTS}

Forty-four patients were evaluated, $65.9 \%$ of them diagnosed with adenocarcinoma, and the majority of patients $(63.6 \%)$ had stage IV neoplasms at the first visit. The characteristics of patients, tumors, and the first treatment are displayed on table 1. All patients were treated at a private organization.

History of neoplasm was reported in five patients, including thyroid cancer (papillary) in one patient; bronchioalveolar cancer in one patient; cervical
Table 1. Demographic and clinical characteristics

\begin{tabular}{|c|c|}
\hline Category & n (\%) \\
\hline \multicolumn{2}{|l|}{ Sex } \\
\hline Female & $22(50.0)$ \\
\hline Male & $22(50.0)$ \\
\hline \multicolumn{2}{|l|}{ Age, years } \\
\hline$\leq 60$ & $22(50.0)$ \\
\hline$>60$ & $22(50.0)$ \\
\hline \multicolumn{2}{|l|}{ Ethnicity* } \\
\hline White & $33(75.0)$ \\
\hline Non-white & $11(25.0)$ \\
\hline \multicolumn{2}{|l|}{ History of neoplasm } \\
\hline Yes & $5(11.9)$ \\
\hline No & $37(88.1)$ \\
\hline \multicolumn{2}{|l|}{ Smoker } \\
\hline Yes & $14(33.3)$ \\
\hline No & $28(66.7)$ \\
\hline \multicolumn{2}{|l|}{ Histological type } \\
\hline Adenocarcinoma & $29(65.9)$ \\
\hline Epidermoid carcinoma & $8(18.2)$ \\
\hline Large-cell carcinoma & $2(4.5)$ \\
\hline Others & $5(11.4)$ \\
\hline \multicolumn{2}{|l|}{ Clinical staging at diagnosis } \\
\hline $\mid A$ & $3(6.8)$ \\
\hline$\| B$ & $1(2.4)$ \\
\hline$\| \mathrm{A}$ & $6(13.6)$ \\
\hline$\| I B$ & $6(13.6)$ \\
\hline IV & $28(63.6)$ \\
\hline \multicolumn{2}{|l|}{ Status at the time of analysis } \\
\hline Alive and with disease in remission & $1(2.3)$ \\
\hline Alive and with disease in activity & $2(4.5)$ \\
\hline Alive and with stable disease & $8(18.2)$ \\
\hline Death with unknown relationship & $5(11.4)$ \\
\hline Death by cancer & $26(59.1)$ \\
\hline Death by other causes & $2(4.5)$ \\
\hline Total & $44(100.0)$ \\
\hline
\end{tabular}

cancer in one patient; breast and colon cancer in one patient.

The mean age of these patients was 63.3 years (standard deviation of 11.3 years), median of 61.1; minimum 43.5, and maximum, 86.5 years. Median follow-up was 47.9 months, varying from 6.78 to 95.69 months, as of the date of the pathological study until the final status. In the overall survival analysis, the median time was 46.3 months, varying from 6.6 to 144.8 months.

In the overall survival analysis, a statistically significant difference was noted between sexes (Table 2). 
There was a greater probability of 60 -month survival for the female group when compared to the males ( $29.4 \%$ versus $15.8 \% ; p=0.042)$. The other variables showed no statistically significant difference (Figures 1 and 2).

Table 2. Overall survival, as per demographic and clinical characteristics

\begin{tabular}{|c|c|c|c|c|c|c|}
\hline \multirow{2}{*}{ Variable } & \multirow{2}{*}{$\begin{array}{c}\text { Cases } \\
\text { (n) }\end{array}$} & \multirow{2}{*}{$\begin{array}{l}\text { Deaths } \\
\text { (n) }\end{array}$} & \multicolumn{3}{|c|}{ Overall survival (\%) } & \multirow{2}{*}{$\begin{array}{c}\mathbf{p} \\
\text { value }\end{array}$} \\
\hline & & & $12 \mathrm{~m}$ & $36 \mathrm{~m}$ & $60 \mathrm{~m}$ & \\
\hline Overall survival & 44 & 33 & 95.5 & 81.1 & 23.3 & - \\
\hline \multicolumn{7}{|l|}{ Sex } \\
\hline Female & 22 & 17 & 95.5 & 95.5 & 29.4 & 0.042 \\
\hline Male & 22 & 16 & 95.5 & 65.8 & 15.8 & \\
\hline \multicolumn{7}{|l|}{ Age (years) } \\
\hline$\leq 60$ & 22 & 14 & 95.5 & 85.1 & 22.3 & 0.288 \\
\hline$>60$ & 22 & 19 & 95.5 & 77.3 & 23.2 & \\
\hline \multicolumn{7}{|l|}{ Ethnicity } \\
\hline White & 33 & 25 & 93.9 & 84.8 & 21.3 & 0.995 \\
\hline Non-white & 11 & 8 & 100.0 & 66.3 & 26.5 & \\
\hline \multicolumn{7}{|l|}{ Smoking } \\
\hline Yes & 14 & 8 & 100.0 & 83.6 & $*$ & 0.847 \\
\hline No & 28 & 23 & 92.9 & 78.1 & 21.6 & \\
\hline \multicolumn{7}{|l|}{ Comorbidities } \\
\hline Yes & 21 & 17 & 95.2 & 85.4 & 18.3 & 0.953 \\
\hline No & 21 & 14 & 95.2 & 75.3 & 14.3 & \\
\hline \multicolumn{7}{|l|}{ Histological type } \\
\hline Carcinoma + other & 15 & 13 & 93.3 & 73.3 & 16.3 & 0.304 \\
\hline Adenocarcinoma & 29 & 20 & 96.6 & 85.2 & 26.7 & \\
\hline \multicolumn{7}{|l|}{$\begin{array}{l}\text { Clinical staging at } \\
\text { diagnosis }\end{array}$} \\
\hline $\mid A$ and $\| B$ & 4 & 3 & 100.0 & 75.0 & $0.0^{*}$ & 0.253 \\
\hline$\||| A$ and $\| \mid B$ & 12 & 9 & 100.0 & 75.0 & 0.0 & \\
\hline IV & 28 & 21 & 92.9 & 84.7 & 33.1 & \\
\hline
\end{tabular}

${ }^{*}$ No patient of this group reached 60 months of survival. Kaplan-Meier test.

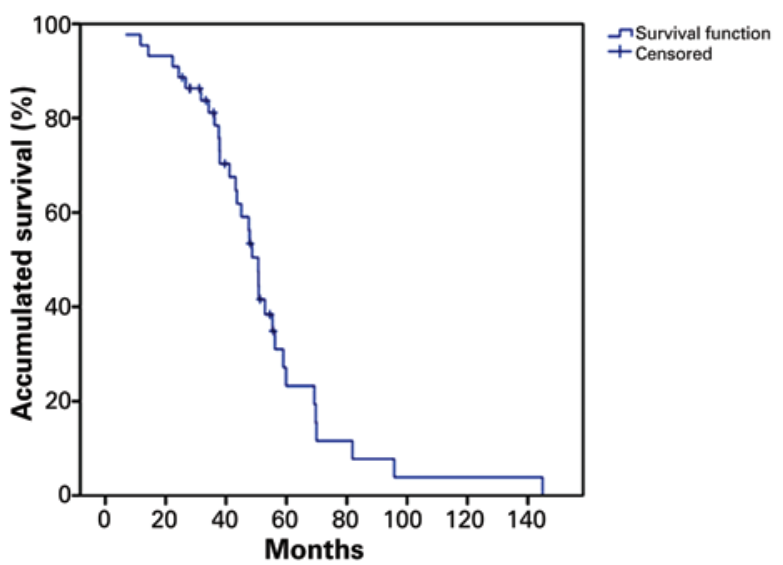

Figure 1. Overall survival (\%) in months. Kaplan-Meier test

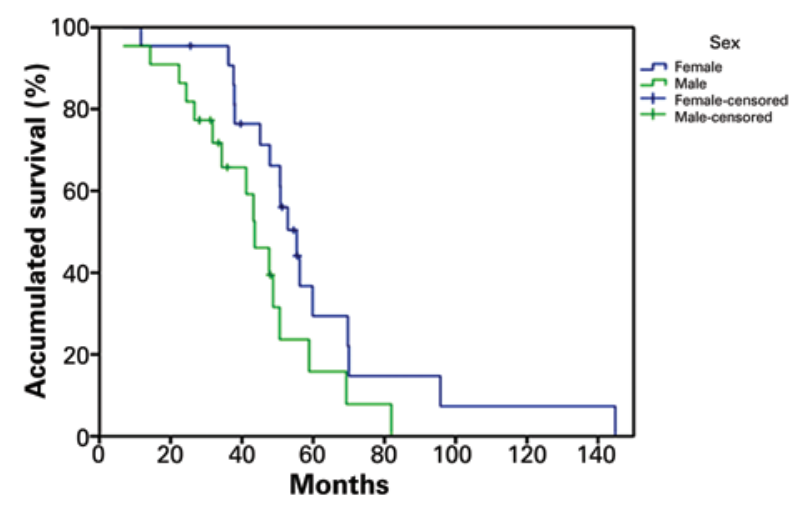

Figure 2. Overall survival (\%) in months, per gender. Kaplan-Meier test

EGFR mutation investigation was done in only $22.7 \%$ of the patients $(n=10)$, with a positive result in $30 \%$ of the patients evaluated, as is seen on table 3 .

Table 3. Patients tested for mutation of the cellular receptor of the epidermal growth factor receptor

\begin{tabular}{lccc}
\hline EGFR & $\mathbf{n}$ & $\begin{array}{c}\text { Investigated } \\
(\%)\end{array}$ & $\begin{array}{c}\text { Total patients } \\
(\%)\end{array}$ \\
\hline Mutated & 3 & 30.0 & 6.8 \\
Non-mutated & 7 & 70.0 & 15.9 \\
Total investigated & 10 & 100.0 & 22.7 \\
EGFR not known & 34 & - & 77.3 \\
\hline Total patients & 44 & - & 100 \\
\hline EGFR: epidermal growth factor receptor. & & &
\end{tabular}

In the analysis of time to treatment failure analysis, a mean of 169.3 days (standard deviation of 144.9) was noted, with a median of 125 days, minimum time of 19 and maximum of 533 days. As to use of erlotinib in different lines, there was no statistically significant difference $(p=0.745)$ in survival. The probabilities of survival in 60 months were for the first, second, and third lines of treatment, $17.1 \%, 41.6 \%, 29.6 \%$, and $37.5 \%$ (Table 4), respectively.

Table 4. Patients who used erlotinib, according to lines of treatment and their respective survivals

\begin{tabular}{lccc}
\hline Lines of treatment & $\begin{array}{c}\text { Cases } \\
\mathbf{n ~ ( \% )}\end{array}$ & $\begin{array}{c}\text { Deaths } \\
(\mathbf{n})\end{array}$ & $\begin{array}{c}\text { Survival 60 months* } \\
(\%)\end{array}$ \\
\hline First & $7(15.9)$ & 6 & 17.1 \\
Second & $20(45.5)$ & 11 & 41.6 \\
Third & $9(20.5)$ & 8 & 29.6 \\
Fourth & $8(18.2)$ & 8 & 37.5 \\
\hline Total & $44(100.0)$ & 33 & \\
${ }^{*}$ Kaplan-Meier test. & & &
\end{tabular}




\section{DISCUSSION}

We conducted a retrospective study in NSCLC patients submitted to the use of erlotinib, treated in a private reference general hospital and a private oncology clinic in São Paulo during the period of January 2004 to December 2011, with a median follow-up of 47.9 months.

In our study we found a greater probability of survival in 60 months for patients of the female gender when compared to the male group $(29.4 \%$ versus $15.8 \% ; \mathrm{p}=0.042)$. EGFR investigation was performed on a small portion of the patients $(n=10 ; 22.7 \%)$, and mutation was present in $6.8 \%$ of the total number of patients $(n=3 ; 30 \%)$. The use of erlotinib was made in patients not selected as to the EGFR status for most of the patients, since this investigation was not demonstrably necessary for the use of this medication at that time.

We found five patients with history of neoplasm. A hypothesis for such a high number is that the institutions where the study was carried out are reference centers for the treatment of neoplasms, and we expected to find patients with a personal and familiar history of neoplasms. ${ }^{(25)}$

In these patients we observed a median survival of 46.3 months, varying from 6.6 to 144.8 months, that is, a little bit above the median found in literature in patients with NSCLC using erlotinib who were not selected as to EGFR. ${ }^{(15)}$ We also noted a statistically significant difference between genders, with a greater probability of survival in 60 months for the female group (29.4\% versus $15.8 \% ; \mathrm{p}=0.042$ ). We should point out that such results include patients not selected as to their EGFR mutation status, since this analysis was not yet proved essential for the use of the medication in the period when the patients were treated.

In our study, the use of erlotinib in different treatment lines did not show a statistically significant difference $(p=0.745)$ in terms of survival. More patients used the second or subsequent lines of treatment, since use as first line therapy was established after the beginning of erlotinib sales. The apparent greater survival in second line treatment compared to the first line did not show statistical significance considering the low number of patients.

Despite the findings, our study had limitations related to its retrospective nature and the small number of patients, impeding greater statistical significance. It is important to point out the lack of information as to the EGFR mutation status in the majority of patients, which has a great influence on the response to the treatment concerned.

\section{CONCLUSION}

Our study included the largest sequence published in Brazil to date, including patients with non-small-cell lung cancer who used erlotinib. It demonstrated that the clinical progression of patients treated in our clinic and hospital, during the period analyzed, had results that agreed with those of current literature in similar patients.

Given the importance of the data presented and limitations, we plan to carry out a new follow-up of these patients as well as of new patients who used erlotinib for non-small-cell lung cancer in the following years. The reason is we will have a growing number of patients who used this medication in the subsequent years when the drug was more widely present in the country.

\section{REFERENCES}

1. Parkin DM, Bray F, Ferlay J, Pisani P. Global cancer statistics, 2002. CA Cancer J Clin. 2005:55(2):74-108.

2. Instituto Nacional de Câncer José Alencar Gomes da Silva (INCA). Coordenação de Prevenção e Vigilância. Estimativa 2014: Incidência de Câncer no Brasil. Rio de Janeiro: INCA; 2014.

3. Beasley MB, Brambilla E, Travis WD. The 2004 World Health Organization classification of lung tumors. Semin Roentgenol. 2005;40(2):90-7. Review.

4. Azzoli CG, Temin S, Aliff T, Baker S Jr, Brahmer J, Johnson DH, Laskin JL, Masters G, Milton D, Nordquist L, Pao W, Pfister DG, Piantadosi S, Schiller JH, Smith R, Smith TJ, Strawn JR, Trent D, Giaccone G; American Society of Clinical Oncology. 2011 Focused Update of 2009 American Society of Clinical Oncology Clinical Practice Guideline Update on Chemotherapy for Stage IV Non-SmallCell Lung Cancer. J Clin Oncol. 2011;29:(28)3825-31. Erratum in: J Clin Oncol. 2011;29(35):4725.

5. Schiller JH, Harrington D, Belani CP, Langer C, Sandler A, Krook J, Zhu J,Johnson DH; Eastern Cooperative Oncology Group. Comparison of four chemotherapy regimens for advanced non-small-cell lung cancer. $\mathrm{N}$ Engl J Med. 2002;346(2):92-8.

6. Leighl NB, Rekhtman N, Biermann WA, Huang J, Mino-Kenudson M, Ramalingam SS, et al. Molecular testing for selection of patients with lung cancer for epidermal growth factor receptor and anaplastic lymphoma kinase tyrosine kinase inhibitors: American Society of Clinical Oncology endorsement of the College of American Pathologists/International Association for the study of lung cancer/association for molecular pathology guideline. J Clin Oncol. 2014;32(32):3673-9.

7. Pao W, Miller V, Zakowski M, Doherty J, Politi K, Sarkaria I, et al. EGF receptor gene mutations are common in lung cancers from "never smokers" and are associated with sensitivity of tumors to gefitinib and erlotinib. Proc Natl Acad Sci U S A. 2004;101(36):13306-11.

8. Eberhard DA, Johnson BE, Amler LC, Goddard AD, Heldens SL, Herbst RS, et al Mutations in the epidermal growth factor receptor and in KRAS are predictive and prognostic indicators in patients with non-small-cell lung cancer treated with chemotherapy alone and in combination with erlotinib. J Clin Oncol. 2005;23(25):5900-9.

9. Tsao AS, Tang XM, Sabloff B, Xiao L, Shugematsu H, Roth J, et al. Clinicopathologic characteristics of the EGFR gene mutation in non-small cell lung cancer. J Thorac Oncol. 2006;1(3):231-9.

10. Marks JL, Broderick S, Zhou O, Chitale D, Li AR, Zakowski MF, et al. Prognostic and therapeutic implications of EGFR and KRAS mutations in resected lung adenocarcinoma. J Thorac Oncol. 2008;3(2):111-6.

11. Maemondo M, Inoue A, Kobayashi K, Sugawara S, Oizumi S, Isobe H, Gemma 
A, Harada M, Yoshizawa H, Kinoshita I, Fujita Y, Okinaga S, Hirano H, Yoshimori K, Harada T, Ogura T, Ando M, Miyazawa H, Tanaka T, Saijo Y, Hagiwara K, Morita S, Nukiwa T; North-East Japan Study Group. Gefitinib or chemotherapy for nonsmall-cell lung cancer with mutated EGFR. N Engl J Med. 2010;362(25):2380-8.

12. Rosell R, Carcereny E, Gervais R, Vergnenegre A, Massuti B, Felip E, Palmero R, Garcia-Gomez R, Pallares C, Sanchez JM, Porta R, Cobo M, Garrido P, Longo F, Moran T, Insa A, De Marinis F, Corre R, Bover I, Illiano A, Dansin E, de Castro J, Milella M, Reguart N, Altavilla G, Jimenez U, Provencio M, Moreno MA, Terrasa J, Muñoz-Langa J, Valdivia J, Isla D, Domine M, Molinier O, Mazieres J, Baize N, Garcia-Campelo R, Robinet G, Rodriguez-Abreu D, Lopez-Vivanco G, Gebbia V, Ferrera-Delgado L, Bombaron P, Bernabe R, Bearz A, Artal A, Cortesi E, Rolfo C, Sanchez-Ronco M, Drozdowskyj A, Queralt C, de Aguirre I, Ramirez JL, Sanchez JJ, Molina MA, Taron M, Paz-Ares L; Spanish Lung Cancer Group in collaboration with Groupe Français de Pneumo-Cancérologie and Associazione Italiana Oncologia Toracica. Erlotinib versus standard chemotherapy as first-line treatment for European patients with advanced EGFR mutation-positive nonsmall-cell lung cancer (EURTAC): a multicentre, open-label, randomised phase 3 trial. Lancet Oncol. 2012;13(3):239-46.

13. Pérez-Soler R, Chachoua A, Hammond LA, Rowinsky EK, Huberman M, Karp $D$, et al. Determinants of tumor response and survival with erlotinib in patients with non--small-cell lung cancer. J Clin Oncol. 2004 15;22(16):3238-47.

14. Zhu CQ, da Cunha Santos G, Ding K, Sakurada A, Cutz JC, Liu N, Zhang T, Marrano P, Whitehead M, Squire JA, Kamel-Reid S, Seymour L, Shepherd FA, Tsao MS; National Cancer Institute of Canada Clinical Trials Group Study BR.21. Role of KRAS and EGFR as biomarkers of response to erlotinib in National Cancer Institute of Canada Clinical Trials Group Study BR.21. J Clin Oncol. 2008;26(26):4268-75.

15. Mok TS, Wu YL, Thongprasert S, Yang CH, Chu DT, Saijo N, et al. Gefitinib or carboplatin-paclitaxel in pulmonary adenocarcinoma. N Engl $\mathrm{J}$ Med. 2009;361(10):947-57.

16. Ellison G, Zhu G, Moulis A, Dearden S, Speake G, McCormack R. EGFR mutation testing in lung cancer: a review of available methods and their use for analysis of tumour tissue and cytology samples. J Clin Pathol. 2013;66(2):79-89. Review.

17. Bezjak A, Tu D, Seymour L, Clark G, Trajkovic A, Zukin M, Ayoub J, Lago S, de Albuquerque Ribeiro R, Gerogianni A, Cyjon A, Noble J, Laberge F, Chan RT, Fenton D, von Pawel J, Reck M, Shepherd FA; National Cancer Institute of Canada Clinical Trials Group Study BR.21. Symptom improvement in lung cancer patients treated with erlotinib: quality of life analysis of the National Cancer Institute of Canada Clinical Trials Group Study BR.21. J Clin Oncol. 2006;24(24):3831-7. Erratum in: J Clin Oncol. 2007;25(1):167.

18. Wheatley-Price P, Ding K, Seymour L, Clark GM, Shepherd FA. Erlotinib for advanced non-small-cell lung cancer in the elderly: an analysis of the National Cancer Institute of Canada Clinical Trials Group Study BR.21. J Clin Oncol. 2008;26(14):2350-7.

19. Pao W, Wang TY, Riely GJ, Miller VA, Pan Q, Ladanyi M, et al. KRAS mutations and primary resistance of lung adenocarcinomas to gefitinib or erlotinib. PLoS Med. 2005;2(1):e17.

20. Shepherd FA, Rodrigues Pereira J, Ciuleanu T, Tan EH, Hirsh V, Thongprasert S, Campos D, Maoleekoonpiroj S, Smylie M, Martins R, van Kooten M, Dediu M, Findlay B, Tu D, Johnston D, Bezjak A, Clark G, Santabárbara P, Seymour L; National Cancer Institute of Canada Clinical Trials Group. Erlotinib in previously treated non-small-cell lung cancer. N Engl J Med. 2005;353(2):123-32.

21. Kim ES, Hirsh V, Mok T, Socinski MA, Gervais R, Wu YL, et al. Gefitinib versus docetaxel in previously treated non-small-cell lung cancer (INTEREST): a randomised phase III trial. Lancet. 2008;372(9652):1809-18.

22. Herbst RS, Prager D, Hermann R, Fehrenbacher L, Johnson BE, Sandler A, Kris MG, Tran HT, Klein P, Li X, Ramies D, Johnson DH, Miller VA; TRIBUTE Investigator Group. TRIBUTE: a phase III Trial of erlotinib hydrochloride (OSI-774) combined with carboplatin and paclitaxel chemotherapy in advanced nonsmall-cell lung cancer. J Clin Oncol. 2005;23(25):5892-9.

23. Garassino MC, Martelli O, Broggini M, Farina G, Veronese S, Rulli E, Bianchi F, Bettini A, Longo F, Moscetti L, Tomirotti M, Marabese M, Ganzinelli M, Lauricella C, Labianca R, Floriani I, Giaccone G, Torri V, Scanni A, Marsoni S; TAlLOR trialists. Erlotinib versus docetaxel as second-line treatment of patients with advanced non-small-cell lung cancer and wild-type EGFR tumours (TAILOR): a randomised controlled trial. Lancet Oncol. 2013;14(10):981-8.

24. Zhou C, Wu YL, Chen G, Feng J, Liu XQ, Wang C, et al. Erlotinib versus chemotherapy as first-line treatment for patients with advanced EGFR mutationpositive non-small-cell lung cancer (OPTIMAL, CTONG-0802): a multicentre, open-label, randomised, phase 3 study. Lancet Oncol. 2011;(8):735-42.

25. Lynch HT, Rubinstein WS, Locker GY. Cancer in Jews: introduction and overview. Fam Cancer. 2004;3(3-4):177-92. Review. 